\title{
A Study on the Impact of Chinese Hierarchical Culture on Chinese Enterprises' Investment Decision
}

\author{
Zhiyuan Zhang \\ School of Economics and Management of Beijing Jiaotong University in Beijing China \\ 1511776273@qq.com
}

Keywords: Hierarchical Culture, Authority, Cash holding, Capital investment.

\begin{abstract}
Economic can be seen as the outer form of a nation's development whereas culture is the inner driver of a nation. The culture will shape and affect the person's preferences and ideas. According to the Upper Echelon theory, as the main decision maker, senior executive team's preferences and behavior will affect the decision-making of the enterprise, especially the investment decision. Different from fickle foreign culture, Chinese traditional culture has a long history and has a profound effect on Chinese, especially hierarchy. Chinese executives are authoritative because they are deeply influenced by the concept of hierarchy, which makes them have the say in many occasions. On the other hand, natural cybernetics and thousands of years of farming economy lead Chinese people to national conservatism, their authority extend the preference. This paper through empirical research find that the authority is negatively correlated with the cash holding, but has a complicated influence of capital investment, which influenced by stock option incentive.
\end{abstract}

\section{Introduction}

Economic can be seen as the outer form of a nation's development whereas culture is the inner driver of a nation. Therefore, the academe has been focused on studying the influence of culture on national economic development, and gradually extended to enterprise. The culture will shape and affect the person's preferences and ideas. According to the Upper Echelon theory, as the main decision maker, the team of senior executives' preferences and behavior will affect the decision-making of the enterprise, especially the investment decision. Different from fickle foreign culture, Chinese traditional culture has a long history and has a profound effect on Chinese people, especially the thousands of years of hierarchy, which can be seen as the unique characteristics compared with foreign culture. The concept of hierarchy makes Chinese have excessive authority for the power. Who has the highest power, who has highest authority. The lower power one will be unconditionally obey the requirements of higher one. Especially in government agencies, "Executive Consciousness" is respected by all the people, all of the workers will be comfortably listen to all instructions from the higher level. Well, in the enterprise, senior management team is considered to be the highest level, so they have enormous control over the enterprise management. Their preferences and behavior will also have a profound impact on business decision-making and development.

\section{Theory basic}

2.1 Cultural Dimensions. In order to make the complex and abstract culture specific, measurable and comparable, foreign scholars constructed a variety of measurement models from different angles, which provides a convenient tool for researching the relationship between culture and economics. Hofstede's cultural dimensions model is recognized and applied widely, which divide the culture into power distance, individualism, masculinity, uncertainty avoidance and long term orientation. China scores in each dimensions are shown in Figure 1ment, time-oriented five dimensions, while China scores in the dimensions shown in Figure 1. 


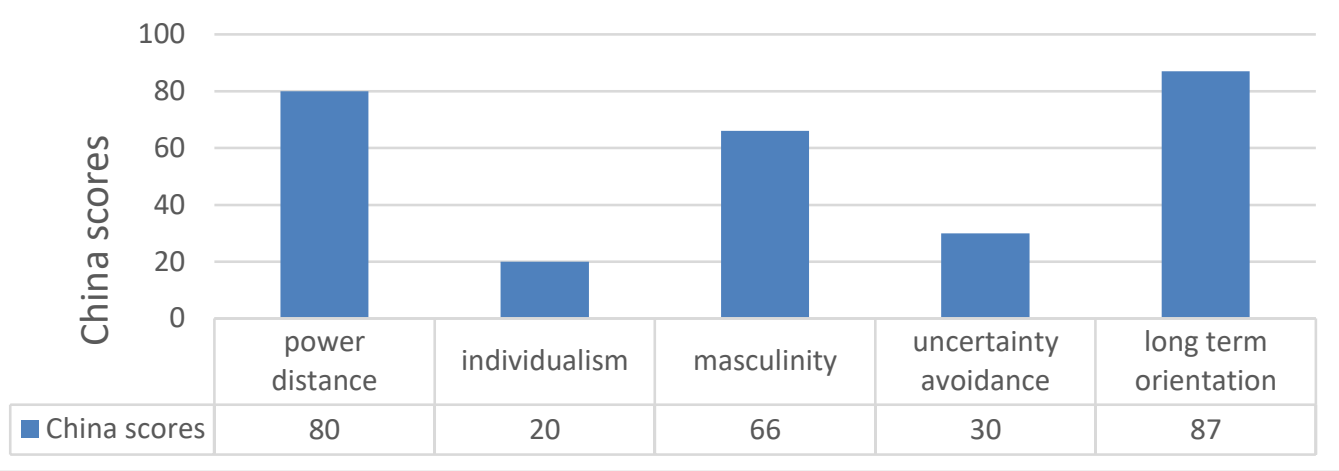

Fig.1 The score of Chinese culture dimensions

Therefore, according to the score and the analysis of existing literature, compared with Western culture, China power distance is larger. In addition, strong long-term orientation makes our people pay attention to the future and frugality. On the other hand, natural cybernetics and thousands of years of farming economy lead Chinese people to national conservatism, which provides the basis for the hypothesis.

2.2 The Upper Echelon Theory. In 1984, American scholars Hambrick and Mason first proposed the "Upper Echelons Theory", which marks the beginning of the executive team research. Its basic idea is that the different values, cognitive bases, insight and other interactions among the members of executive team will have a great influence on the enterprise strategy choice and performance. According to this theory, the author defines the research object as CEO, chairman secretary, general manager, deputy general manager and chief financial officer. Besides, using the background characteristics of the population as an intermediate variable to measure the authoritative culture, so that to study the relationship between investment and authoritative culture.

\section{Establish model}

3.1 Model Hypothesis. According to the existing research, the relationship between culture preference and individual preference, risk preference and enterprise investment decision can be summarized as Fig.2.

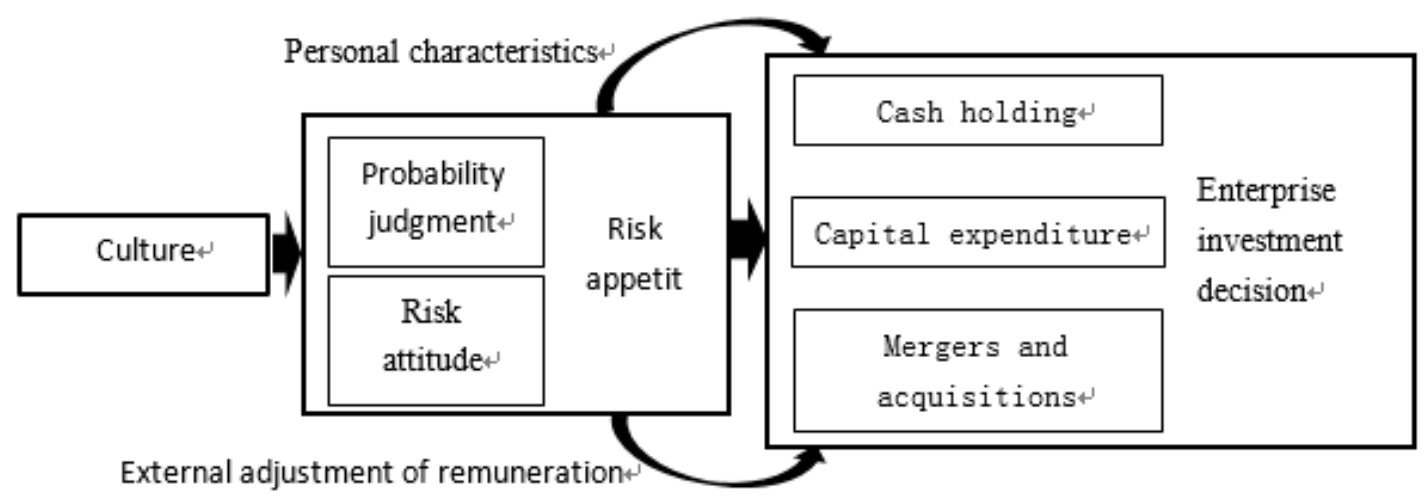

Fig. 2 The relationship between culture and enterprise investment

Culture influences managers' risk preference by influencing their risk attitudes and managers' probability judgments of risk. While managers have the right to make majority of the decisions, which allows their personal preferences and attitudes to influence the decision-making of the company. (Yuan Zhang). The investment decision-making includes cash holding, capital expenditure, M \& A. Many scholars through the empirical study found that the more conservative, more cash holdings(Chang \& Noorbakhsh), less capital investment(Coles\& Naveen), and lower frequency of acquisitions (Graham \& Puri).

China's hierarchical culture gives the power to the authority. In enterprise, employees will be unconditionally obey the executive team, who were considered as the highest controller, requirements and decision-making, which will affect the freedom of business decision-making in a certain extent. 
To the executive team, it is necessary to maintain a certain level of corporate performance to make the company develop steadily, so that they will have a steady income. All these lead to maintain more cash and other high current assets and reduce capital investment. The authority extend the tendency of conservative. Therefore, this paper presents the following hypothesis.H1: authoritative and cash holdings are positively correlated. $\mathrm{H} 2$ : Authority is negatively correlated with capital investment.

3.2 Sample selection. This paper chooses the data of Chinese manufacturing companies listed in Shanghai and Shenzhen Stock Exchange from 2013 to 2015 as the samples. And the data were handled as follows. (1) Remove ST companies. (2) According to the definition of executive team selected the data of CEO, chairman secretary, general manager, deputy general manager and chief financial officer. (3) Exclude the company with less than 4 executives. (4) Divided the enterprises into state-owned and non-state-owned according to the actual control. Finally, the sample include 1363 enterprises, 10724 executives, 454 state-owned enterprises, 909 non-state-owned enterprises.

3.3 Variable design. Scholars have several ways to measure the authority. (1) Tenure(Hanru Liao, Wei Li); (2)Shareholding ratio(Hanru Liao);(3) Political connections(Jing Zhang);(4) Power distance. So this paper refers to the predecessor's research, select the tenure, power distance and executives shareholding ratio as the measure. The longer the average tenure and the higher the shareholding ratio, the higher authority of the executives. While the greater distance of the power, the more representative of authority, that is to say it play a regulatory role to overall authority.

Based on the relationship between culture and enterprise investment and the related research, this paper find that culture has an influence on cash holding decision-making and capital expenditure strategy. At the same time, these two decisions also reflect the investment term structure. So the author choose cash holding and capital investment as an explanatory variable, measuring business investment decisions.

According to the existing research in this field, choose firm size, firm intensity and capital structure as control variable. The large company has a solid economic support for risking. With the development of the times and globalization, the foreign cultural pluralism impact the young people, so their acceptability of traditional culture is reduced. Therefore, the degree of enterprises' rejuvenation is negatively correlated with authoritative cultural acceptance. All the variables in this paper are summarized in Table 1.

Table1. The definition of variable

\begin{tabular}{|c|c|c|c|}
\hline Variables & Name & Symbol & Definition \\
\hline \multirow{3}{*}{$\begin{array}{l}\text { Independent } \\
\text { variable }\end{array}$} & Tenure & ATEN & The average time for the current position \\
\hline & $\begin{array}{l}\text { executives } \\
\text { shareholding }\end{array}$ & SHR & Executives holding shares/whole shares \\
\hline & power distance & PDVC & $\begin{array}{l}\text { Non general manager or CEO is } 1 \text {; general } \\
\text { manager or CEO is } 2 \text {; general manager and CEO } \\
\text { is } 3 \text {, then use standard deviation / average }\end{array}$ \\
\hline \multirow[t]{2}{*}{$\begin{array}{l}\text { Dependent } \\
\text { variable }\end{array}$} & cash holding & FCF & $\begin{array}{l}\text { (Monetary funds }+ \text { transactional financial assets) / } \\
\text { total assets }\end{array}$ \\
\hline & $\begin{array}{l}\text { capital } \\
\text { investment }\end{array}$ & CAPI & $\begin{array}{l}\text { Construction of fixed assets, intangible assets and } \\
\text { other assets Cash / total assets }\end{array}$ \\
\hline \multirow[t]{3}{*}{ Control variable } & firm size & ESIZE & total assets \\
\hline & capital structure & ALR & asset-liability ratio \\
\hline & firm intensity & TAGE & The average age of executive team \\
\hline
\end{tabular}

\section{Empirical Analysis}

4.1 Descriptive statistics. Descriptive statistic analysis based on the samples through SPSS shows in table 2 . 
Table2. Description of the variable

\begin{tabular}{llllll}
\hline \multicolumn{1}{c}{ Variables } & Symbol & Minimum & Maximum & Average & Standard deviation \\
\hline \multirow{2}{*}{$\begin{array}{l}\text { Independent } \\
\text { variable }\end{array}$} & ATEN & 0.42 & 13.40 & 4.63 & 2.05 \\
\cline { 2 - 6 } & SHR & $0.00 \%$ & $83.00 \%$ & $10.55 \%$ & $17.38 \%$ \\
\cline { 2 - 6 } & PDVC & $0.00 \%$ & $70.71 \%$ & $41.07 \%$ & $10.62 \%$ \\
\hline \multirow{2}{*}{$\begin{array}{l}\text { Dependent } \\
\text { variable }\end{array}$} & FCF & $0.13 \%$ & $72.43 \%$ & $31.15 \%$ & $11.61 \%$ \\
\cline { 2 - 6 } Control variable & CAPI & $0.00 \%$ & $40.28 \%$ & $4.68 \%$ & $4.74 \%$ \\
\cline { 2 - 6 } & ESIZE & 45869096 & 511630705000 & 9780079951 & 25742551658 \\
\cline { 2 - 6 } & ALR & $1.97 \%$ & $127.96 \%$ & $41.48 \%$ & $19.80 \%$ \\
\cline { 2 - 6 } & TAGE & 36.14 & 63 & 48.39 & 3.35 \\
\hline
\end{tabular}

First, about cash holding level, the average is $31.15 \%$, even its maximum reached to $72.43 \%$. That is to say, nearly $1 / 3$ of the total assets is cash assets. Thus it can be seen that the company has a lot of idle capital and its investment decisions tend to conservative, which also reflects a certain degree of conservative preferences of our executives. Second, about the capital investment, the average proportion of the fixed assets, intangible assets investment to total assets is $4.68 \%$, the highest is $40.28 \%$, but the lowest is 0 . That is to say, no fixed assets or intangible assets were invested these years. Compared with cash holdings, investment in fixed assets is seldom. All these Show that enterprises prefer to investing short-term assets and rarely put into long-term high-risk assets. Forth, about the authoritative, the average tenure of executives is 4.63 years. In general, the time is long, which is longer than the legal term (3 years) of the directors and supervisors. The average executives' shareholding ratio can reach to $10.55 \%$, indicating the authority of the executives is quite obvious.

\subsection{Regression analysis}

4.2.1Regression Analysis of Authoritative and Cash Holding. The results of regression analysis of authoritative and cash holding using SPSS analysis was shown in Table 3.

Table3. Regression results of cash holding

\begin{tabular}{|c|c|c|c|c|c|c|}
\hline \multirow[t]{2}{*}{ Variables } & \multicolumn{2}{|c|}{ Total } & \multicolumn{2}{|c|}{ State-owned } & \multicolumn{2}{|c|}{ Non-state-owned } \\
\hline & $\mathrm{B}$ & Sig. & $\mathrm{B}$ & Sig. & $\mathrm{B}$ & Sig. \\
\hline (Constant) & 19.743 & 0 & 13.256 & 0.015 & 28.854 & 0 \\
\hline PDVC & 0.071 & 0.024 & 0.072 & 0.018 & 0.062 & 0.027 \\
\hline ATEN & -0.308 & 0.052 & 0.01 & 0.041 & -0.5 & 0.013 \\
\hline ESIZE & 0.002556 & 0.042 & 0.001492 & 0.012 & 0.0005829 & 0.032 \\
\hline ALR & -0.154 & 0 & -0.14 & 0 & -0.168 & 0 \\
\hline SHR & -0.02 & 0.056 & -0.086 & 0.076 & -0.02 & 0.034 \\
\hline TAGE & -0.078 & 0.047 & -0.563 & 0.009 & -0.038 & 0.041 \\
\hline $\mathrm{R}^{2}$ & & 0.177 & & 0.204 & & 0.138 \\
\hline Adjust $\mathrm{R}^{2}$ & & 0.162 & & 0.184 & & 0.116 \\
\hline $\mathrm{F}$ & & 11.238 & & 5.157 & & 8.036 \\
\hline Sig. & & $.000^{\mathrm{a}}$ & & $.000^{\mathrm{a}}$ & & $.000^{\mathrm{a}}$ \\
\hline
\end{tabular}

From the overall regression result, the adjust $\mathrm{R}^{2}$ of total sample, state-owned enterprise and nonstate-owned enterprise is $0.167 、 0.184 、 0.116$, the $\mathrm{F}$ values were $11.238,5.157$ and 8.036 , and the significant level is high. All these indicate that the overall model is effective. The assumptions and the relationship between the authoritative variables and the cash holdings are summarized in table 4 .

Table 4 Regression results of cash holding

\begin{tabular}{cccc}
\hline $\begin{array}{l}\text { Independent } \\
\text { variable }\end{array}$ & The relationship & Significant level & $\begin{array}{c}\text { Consistent with the } \\
\text { assumptions }\end{array}$ \\
\hline PDVC & + & $* * *$ & $\mathrm{Y}$ \\
\hline ATEN & - & $*$ & $\mathrm{~N}$ \\
\hline SHR & - & $*$ & $\mathrm{~N}$ \\
\hline
\end{tabular}

Note:* Indicates significant level of $10 \%$, ** indicates 5\%, and *** indicates $1 \%$.

The executive power distance is negatively correlated with the cash holding level and the significance level is high, which supports the hypothesis. Shareholding ratio and the average tenure are negatively correlated with the cash holdings, but the significance is not very high. This may be 
due to the power distance is a measure of internal power stratification. The high power distance indicate the high imbalance of the power, which make some senior executives' power too high to master the decision-making power of enterprises. It will extend the influence of authority and tend to conservative investment, holding more cash. The negative correlation between executive tenure and cash may be due to the growth of tenure, the growth of senior executives' experience and the familiarity to enterprises and industries, so it has some correcting effect on conservative preference. The negative correlation between executive shareholding and cash may be externally influenced by equity incentives, making the managers want to increase the value of the company more quickly, so that they can obtain more earnings. So they quit holding cash which has low investment returns and invest in high-yielding assets. In contrast to state-owned and non-state-owned enterprises, we find that the proportion of holdings is more significant for non-state-owned enterprises, because the latter one has more autonomy to implement equity incentives for senior executives. In terms of tenure, the longer the term of senior executives, the more inclined to high cash holdings. Because many stateowned enterprises executives appointed by the government, which lead a low mobility of the managers compared to non-state-owned enterprises. And the promotion mechanism of state-owned enterprises is relatively curing, so the length of their tenure is a very important factors for promotion. Long-term executives is with higher authority, and high job stability also makes them pay more attention to develop steadily rather than rapidly, so their conservative preferences increase, resulting in preferring investing low-risk and high-stability items like cash.

About the control variables, the larger the size of the company, the greater the amount of cash held, since more cash needs to support operating per day to prevent a break in capital chain and reduce the property of bankruptcy. The higher the asset-liability ratio, the lower the solvency of enterprises, on the other hand the higher the risk, so the enterprise remain less low-risk asset investment — - the cash assets. The lower the degree of business activity, that is, the higher the average age of executives, they are more likely to pursue to stable life, more inclined to risk aversion, so they will remain more high fluidity asset.

4.2.2Regression Analysis of Authoritative and Capital Investment. The results of regression analysis of authoritative and capital investment using SPSS analysis was shown in table 5.

Table5. Regression results of capital investment

\begin{tabular}{|c|c|c|c|c|c|c|}
\hline \multirow[t]{2}{*}{ Variables } & \multicolumn{2}{|c|}{ Total } & \multicolumn{2}{|c|}{ State-owned } & \multicolumn{2}{|c|}{ Non-state-owned } \\
\hline & B & Sig. & $\mathrm{B}$ & Sig. & $\mathrm{B}$ & Sig. \\
\hline (Constant) & 5.461 & 0.015 & 9.482 & 0.012 & 2.973 & 0.019 \\
\hline PDVC & -0.006 & 0.122 & -0.009 & 0.147 & -0.008 & 0.046 \\
\hline ATEN & -0.003 & 0.061 & 0.044 & 0.047 & -0.073 & 0.029 \\
\hline ESIZE & 0.0004799 & 0.027 & 0.000796 & 0.055 & 0.0009343 & 0.015 \\
\hline ALR & 0.005 & 0.027 & -0.012 & 0.029 & 0.018 & 0.025 \\
\hline SHR & 0.039 & 0 & -0.068 & 0.061 & 0.038 & 0 \\
\hline TAGE & -0.034 & 0.103 & -0.11 & 0.086 & 0.031 & 0.056 \\
\hline $\mathrm{R}^{2}$ & & 0.141 & & 0.138 & & 0.131 \\
\hline Adjust $R^{2}$ & & 0.134 & & 0.116 & & 0.12 \\
\hline $\mathrm{F}$ & & 5.754 & & 2.853 & & 2.857 \\
\hline Sig. & & $.000^{\mathrm{a}}$ & & $.000^{\mathrm{a}}$ & & $.002^{\mathrm{a}}$ \\
\hline
\end{tabular}

From the overall regression result, the adjust R2 of total sample, state-owned enterprise and nonstate-owned enterprise is $0.141,0.138$ and 0.131 , the $F$ values were 5.754, 2.853 and 2.857, and the significant level is high. All these indicate that the overall model is effective. The assumptions and the relationship between the authoritative variables and capital investment are summarized in table 6. 
Table 6. Regression results of capital investment

\begin{tabular}{cccc}
\hline $\begin{array}{l}\text { Independent } \\
\text { variable }\end{array}$ & The relationship & Significant level & $\begin{array}{c}\text { Consistent with the } \\
\text { assumptions }\end{array}$ \\
\hline PDVC & - & - & Y \\
\hline ATEN & - & $*$ & Y \\
\hline SHR & + & $* * *$ & $\mathrm{~N}$ \\
\hline Indicates significant level of $10 \%, * *$ indicates 5\%, and *** indicates 1\%.
\end{tabular}

The results show that the executive power distance and executive term are negatively correlated with the capital expenditure investment, which supports the hypothesis, but the significance is low. While executives shareholding ratio has significant positive correlation with capital investments, which is inconsistent with the hypothesis. The reason why the conclusion of authoritative and conservative capital investment is not significant is that the company's major capital investment can't be directly decided by the executives, need to be audited by the shareholders and the board of directors, so the authoritative of executives works a little. The contrary conclusion of executives' shareholding can be interpreted as the share holdings owned by the Chinese executives, which make them fully related to enterprise development and act as master, has made an adjustment to conservative preference, so that they expect to invest in long-term high-income assets, improve business performance. From the comparison of state-owned enterprises and non-state-owned enterprises, we can also found the diversity influence of executives' shareholding ratio. As state-owned company has less equity incentive, so the executives still use its authority to show long-term project risk aversion.

About other control variables, the larger company has more powerful strength and more funds to invest capital, so it's positively correlated with the capital investment. The reason for the positive correlation relationship between capital structure and capital investment is the higher the assetliability ratio, indicating the higher the degree of its debt, the more funds borrowed to invest other items. The conclusion of the enterprise vitality is analogous to the section of cash flow. The higher the average age of executives, they are more likely to pursue to stable life, so the more conservative risk appetite, invest less long-term high-risk capital investment.

\section{Conclusion}

Through the above descriptive statistics and regression analysis, we can find that Chinese executives are authoritative because they are deeply influenced by the concept of hierarchy, which makes them have the say in many occasions. Conservative preference does make corporate cash holding high. Power distance has great influent on cash holdings but not on capital investment. The conclusion of the proportion of executives' shareholding is contrary with the hypothesis. This can be interpreted as the share holdings owned by the Chinese executives has made an adjustment to conservative preference. I believe that this may be affected by the external effects of equity incentives, but at the same time I think it is still a measure of authority because from the comparison of state-owned enterprises and non-state-owned enterprises we can find that since state-owned enterprises have less equity incentive, Chinese executives tend to avoid risk in long-term projects. So the executive shareholding ratio can be seen as a multivariable that depends on the level of incentives. Therefore, if we want to weaken the influence of authoritative preference on corporate conservative preference, we must improve the company's long-term equity incentive mechanism. Through such means we can make the interests of executive, company and shareholders fully integrated. Executives will no longer act merely like agents. In order to maintain company's operations and their own interests, they will act as heroes, and strive to accelerate the development of the company, and expand authoritative culture to a positive direction to fully improve the company's conservative investment decisions.

\section{References}

[1] Yuan Zhang, The Theory and Empirical Research on the Impact of Regional Culture and Risk Preference on Corporate Investment Decision, Central South University,2012 
[2] Chang K, Noorbakhsh A. Does national culture affect international corporate cash holdings?, Multinational Financial Management, vol.19(5), pp. 323-342, 2009.

[3] Coles J L, Daniel N D, Naveen L. Managerial incentives and risk-taking. Financial Economics, vol. 79(2), pp. 431-468, 2006.

[4] Graham J R, Harvey C R, Puri M. Capital allocation and delegation of decision-making authority within firms. Unpublished working paper, 2010.

[5] Hanru Liao, Study on Relationship between Cultural Background of Chinese Senior Executive and Conservative Trend of Enterprise Investment, Southwestern University of Finance and Economics, 2014.

[6] Jing Zhang, Research on the Influence of Political Connection on Private Enterprises Investment Preferences, Dalian University of Technology, 2015.

[7] Ricky Y. K. Chan, Louis T. W. Cheng and T. Y. Leung, Corporate Performance Implications of Relational Demographic Differences: On Age and Titles of Chairpersons versus General Managers of Listed Chinese Companies, British Journal of Management, vol. 22, pp. 96113,2011 .

[8] Blader, S. L., Chen, Y. R.. Differentiating the Effects of Status and Power: A Justice Perspective. Journal of Personality and Social Psychology, vol102(5), pp.994-1014,2012. 